\title{
Correction to: How do combinations of unhealthy behaviors relate to attitudinal factors and subjective health among the adult population in the Netherlands?
}

\author{
Charlotte M. Dieteren ${ }^{1 *}$, Werner B. F. Brouwer ${ }^{1,2}$ and Job van Exel ${ }^{1,2}$
}

\section{Correction to: BMC Public Health 20, 441 (2020) \\ https://doi.org/10.1186/s12889-020-8429-y}

It was highlighted that in the original article [1] the graphs in Fig. 1 were duplicated. This Correction article shows the correct Fig. 1. The original article has been updated.

\footnotetext{
Author details

'Erasmus University Rotterdam, Erasmus School of Health Policy \& Management, P.O. Box 1738, 3000, DR, Rotterdam, the Netherlands. ${ }^{2}$ Erasmus University Rotterdam, Erasmus School of Economics, Rotterdam, The Netherlands.
}

Published online: 27 November 2020

\section{Reference}

1. Dieteren, et al. How do combinations of unhealthy behaviors relate to attitudinal factors and subjective health among the adult population in the Netherlands? BMC Public Health. 2020;20:441 https://doi.org/10.1186/ s12889-020-8429-y.

The original article can be found online at https://doi.org/10.1186/s12889020-8429-y.

* Correspondence: dieteren@eshpm.eur.nl

${ }^{1}$ Erasmus University Rotterdam, Erasmus School of Health Policy \& Management, P.O. Box 1738, 3000, DR, Rotterdam, the Netherlands

Full list of author information is available at the end of the article

(c) The Author(s). 2020 Open Access This article is licensed under a Creative Commons Attribution 4.0 International License, which permits use, sharing, adaptation, distribution and reproduction in any medium or format, as long as you give appropriate credit to the original author(s) and the source, provide a link to the Creative Commons licence, and indicate if changes were made. The images or other third party material in this article are included in the article's Creative Commons licence, unless indicated otherwise in a credit line to the material. If material is not included in the article's Creative Commons licence and your intended use is not permitted by statutory regulation or exceeds the permitted use, you will need to obtain permission directly from the copyright holder. To view a copy of this licence, visit http://creativecommons.org/licenses/by/4.0/. The Creative Commons Public Domain Dedication waiver (http://creativecommons.org/publicdomain/zero/1.0/) applies to the data made available in this article, unless otherwise stated in a credit line to the data. 


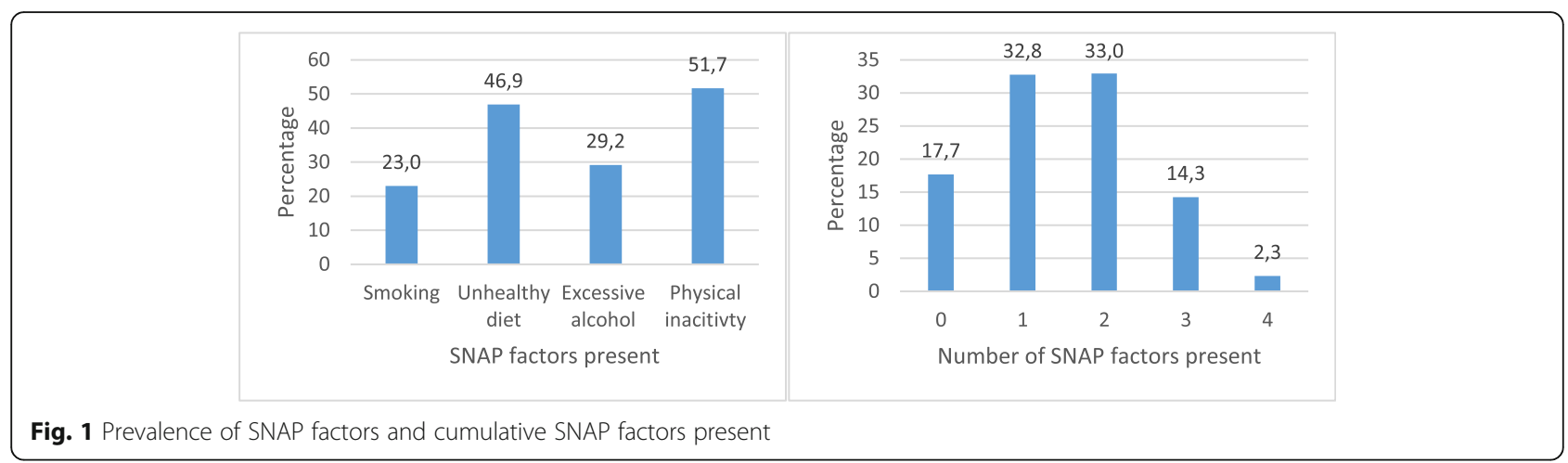

